UDC 340.115

DOI https://doi.org/10.32849/2663-5313/2021.10.01

Nataliia Protskiv,

PhD in Law, Associate Professor, Associate Professor at the Department of Private Law, Yuriy Fedkovych Chernivtsi National University, 19, Universytetska street, Chernivtsi, Ukraine, postal code 58012,n.protskiv@chnu.edu.ua

ORCID: orcid.org/0000-0002-2182-4936

Oksana Kiriiak,

PhD in Law, Associate Professor, Associate Professor at the Department of Private Law, Yuriy Fedkovych Chernivtsi National University, 19, Universytetska street, Chernivtsi, Ukraine, postal code 58012,o.kiriyak@chnu.edu.ua

ORCID: orcid.org/0000-0001-8850-805X

Protskiv, Nataliia, Kiriiak, Oksana (2021). A closer look at private law methodology. Entrepreneurship, Economy and Law, 10, 5-9, doi https://doi.org/10.32849/2663-5313/2021.10.01

\title{
A CLOSER LOOK AT PRIVATE LAW METHODOLOGY
}

Abstract. The purpose of this article is to substantiate the influence of the methodology of private law on the processes of law-making and law enforcement. Pursuing the goal of presenting broad coverage of the issue, the authors tend towards a narrative style that favors simplicity over generality or rigor.

Research methods. The also applied mixed methods in identifying frameworks of private law and their relative visibility striving to allay bias inherent in a single method. Thus, it is distinguished two main branches of the research methods being used in this article: general scientific and special methods of scientific knowledge.

Results. The conclusion summarizes the article's main arguments by suggesting the new definition of term "methodology" through two key meanings: 1) a system of methods and techniques used in a particular field of activity and 2) the doctrine of such a system as general theory of method, theory in action. To put it another way, this article starts where most of previous studies have given up: it has been concluded such main features of the method of regulation of private law relations, as legal equality of participants, free will of the parties, their initiative, property independence, use of dispositive norms. It is noted that the methodology is also based on a system of principles, which are also enshrined in Article 3 of the Civil Code of Ukraine due to the implementation of the rules private international law in national law become, the rules formulated in the Principles, Definitions and Model Rules of Private European Law (DCFR), Principles of European Contract Law (PECL), Principles of European Law (PEL), Principles of European Insurance Law, Principles of Acquis, Principles of UNIDROIT.

Conclusions. The results of our empirical analysis provide strong evidence that the interaction between theory and practice in methodology should be the basis of the study, because it is the methodology which solves the problems posed by practice and vice versa, the problems of practice lead to the creation of rational legal constructions.

Key words: methodology, practice, principles, methods, norms, private law.

\section{Introduction}

The current state of development of society and the state, achievements of domestic legal thought - despite the large number of scientific papers on the problems of methodology requires the search for new scientific approaches, principles and methods of scientific knowledge, deepening and specialization of the methodology of knowledge. Methodology as a field of scientific knowledge has an interdisciplinary nature; it has a special place in the system of sciences. Being a general scientific phenomenon, structural methodology covers a range of components, among which are a system of methods and doctrines about them, a certain worldview of the researcher and general theoretical principles.

The goal of this article is to substantiate the influence of the methodology of private law on the processes of law-making and law enforcement. Pursuing the goal of presenting broad coverage of the issue, the authors tend towards a narrative style that favors simplicity over generality or rigor. The also applied mixed methods in identifying frameworks of private law and their relative visibility striving to allay bias inherent in a single method. Thus, it is distinguished two main branches of the research 
methods being used in this article: general scientific and special methods of scientific knowledge.

2. Underlying origins of private law methodology

The empirical evidence presented in this chapter proves that it is currently important to study the practical problems of private law, as well as the interpretation of the content of positive law. According to Andrew S. Gold et al., a thread that runs throughout New Private Law theory is an interest in the internal point of view that is combined with an interest in empirical research, functional analysis, or the practical effects of legal doctrine (Gold et al., 2019, p. 2-3). The European legal tradition prides the foundations of its laws were laid down by the ancients (de Bérier, 2015). With respect to the research field, the authors turn their attention to examining the way judicial review principles developed over centuries to control dominant state-based power - can be adapted to regulate the contractual relations between powerful private organizations and ordinary citizens. This may have wide-ranging implications, including a growing irrelevance of judicial review procedure and contract law doctrines exerting at least an anchoring effect on the way judicial review principles evolve (Liang, 2020, p. 427-428). However, it should be noted that methodology is of great importance for the processes of lawmaking and law enforcement; it allows improving and making more effective practice. Legal practice in various forms of its manifestation is determined by some factors. Thus, the end result depends on one who acts (subject), on what it is focused (object), and how such a process is carried out (used methods, techniques, means).

There is the same dynamics during the construction of private legal schemes (Verstein, 2019, p. 557). Methodology has a multifaceted nature: it consists of philosophy, which in combination with dialectics, epistemology and logic, performs in the cognitive process an important task of subjective understanding of objective development. Methodology is multilevel, which makes it possible to use a variety of tools to comprehensively characterize the object of knowledge, from its analysis at the categorical level, using dialectical and metaphysical approaches and ending with the study of this object based on knowledge not only of law but also other sciences.

Some domestic scientists distinguish between general and branch methodology. General methodology is an in-depth approach to the study of all objects and phenomena of the world with using cognitive tools of philosophy. At the highest, second level - in branch methodology - there is a choice of general methodological arsenal of appropriate starting points for the implementation of specific cognitive tasks.

Foreign scholars note that methodology is a special branch of the theory of cognition, which is a logical justification of the historical path, means, methods of research in various fields. In the methodology of scientific knowledge, a pride of place belongs to the methodology of legal science. The methodology of private law quickly adapts to the regulation of modern relations and produces such mechanisms, which are characterized by a high degree of flexibility and they effectively meet the challenges of modern society. The current regulation does not add a comprehensive set of rules but contains various gaps in their substantive scope that make it necessary to rely on other sources of private law (Rühl \& von Hein, 2015, p.703).

Although there are many issues for discussion, one key issue emerges: a new public-private law paradigm is developing with respect to the state's role in private contracts. The paradigm melds private law concepts, e.g., mala fides, good faith, and relevant handling with the general human rights principles of dignity and vulnerability (Barnes, 2020, p. 91). Common law represents an ongoing negotiation between past precedents and present-day principles and policies, if the basis of the common law and judicial review is the courts duty to protect the individual from the effects of dominant power; thus, we must look to where that dominant power will increasingly reside (Liang, 2020, p. 427-428).

In turn, we should agree with R. Maidanyk, who believes that "the methodology of private law reflects the specifics of subjective civil rights and interests, their relations with public rights and interests, which determines the application or the presence of unknown public law methods, principles and legal constructions» (Maidanyk, 2019, p. 58). The concept of "methodology" has two main meanings: a system of methods and techniques used in a particular activity, and the doctrine of such a system, i.e., the general theory of the method, the theory in action. O. Yuldashev proposes to consider the methodology of private law as "a component of the system of methodology of state and law. This system should be three-level and cover: 1) the methodology of private law philosophy; 2) methodology of private law theory; 3) the methodology of private law, which must have methodological and methodi levels (Yuldashev, 2004, p. 63). ples

3. Contextualization of private law princi-

Considering the issue of private law methodology, it is necessary to pay attention to 
the method of private law, i.e., the way it affects public relations. However, these concepts can be identified in no way. Method (in Greek «methodos») means the way an entity operates in any form. Method is a subsystem of law methodology. The method combines methods of studying law. Methods are characterized by the following features: the presence of a set of methods, tools, techniques by which the subject of science is studied; it is carried out by a certain sequence of actions, using in the process of cognition, a specific object, the appropriate tools; this sequence is aimed at achieving the goal set by the researcher; these goals can vary: from gaining new knowledge to generalization, evaluation, systematization of existing knowledge; goals are classified into theoretical (cognitive) and practical.

Classifying the methods of legal science, P. M. Rabinovych distinguishes: general scientific methods, i.e., those used in all or most sciences (methods of structural, functional, convergence from abstract to specific; formally logical procedures - analysis, synthesis, etc.); group methods, i.e., those that are used only in a particular group of sciences. Special methods, i.e., adopted for the study of the subject of a single science: for example, in jurisprudence - clarification (interpretation) of legal norms, special methods of generalization of legal practice (Rabinovych, 2001, p. 618).

In private law, the method is dispositive, permissive, i.e., it allows participants in the relations to act freely within the statutory relations. However, according to V. V. Vasiliev "the presence in the rule of law of norms of conduct, at least variable, is not a manifestation of dispositiveness due to the lack of possibility of its concretization or the formation of an alternative model. Similarly, the possibility of refusing to exercise subjective civil right is not a manifestation of dispositiveness (Vasiliev, 2018, p. 13).

The specificity of the method of private law is that the state takes a minimal part in it, and therefore the subjects receive certain rights as a result of their purposeful actions, initiative, property independence, use of dispositive norms. It is worth agreeing with the position of O. D. Krupchan, who believes that "the objective basis of any scientifically verified legal methodology and the starting point of legal activity based on its principles is a certain system of principles. After all, the principles of law most emphatically reveal the goals of legal regulation, the desire for practical implementation of which leads to the design and implementation of various legal means (Krupchan, 2016, p. 13). The same considerations are shared by some foreign researchers of private law, who emphasize the crucial importance of studying the princi- ples of law in the methodological context (Bar, Clive, \& Schulte-Nölke, 2009, p. 542).

Such principles are enshrined in Art. 3 of the Civil Code of Ukraine: 1) inadmissibility of arbitrary interference in the sphere of personal life; 2) inadmissibility of deprivation of property rights, except in cases established by the Constitution of Ukraine and the law; 3) freedom of contract; 4) freedom of entrepreneurial activity, which is not prohibited by law; $5)$ judicial protection of civil rights and interests; 6) justice, good faith and reasonableness. The above general principles of civil law regulation apply to the entire private law. T. V. Bodnar notes that "the principles of civil law have a practical orientation, which is manifested in the fact that they are: norms of direct action; are taken into account when developing new or replacing old regulations; they should be guided in case of need to apply the analogy of law; they must be taken into account when interpreting the rule of law or the content of the contract; serve as an aid to overcoming contradictions between legal norms (Bodnar, 2007, p. 110).

The principles of law determine the general direction, high quality, and the effectiveness of law-making and practical activity in any civilized society. A. S. Dovgert identifies "norms-principles of natural private law, which belong to the uniform norms of law. These include bona fides (good faith, justice, reasonableness), the human right to honor and dignity, property rights, principles of freedom of contract, compensation for damage, etc. (Dovgert, 2012, p. 249).

Given the implementation of private international law in national law, the principles formulated in the "Principles, Definitions and Model Rules of European Private Law" - the scientific "Draft General Reference Scheme" - Principles, Definitions and Model Rules of European Private Law - Draft Common Frame of Reference (Principles, Definitions and Model Rules of European Private Law, 2009). The Model Rules consist of 10 books, each article of which is accompanied by a commentary explaining the content of its provisions, as well as notes that contain an overview of the legal regulation of certain issues under EU law, national law of EU member states and international unified documents. Worth noting are the documents that preceded them: Principles of European Contract Law (PECL), Principles of European Law (PEL), Principles of European Insurance Law, Principles of Acquis, Principles of UNIDROIT. An analysis of the case law of the Court of Justice shows that in cases of competition or conflict between a rule of EU law and a principle of law, the latter will be preferred. As a body of law, it is not restricted to specific rules that 
are only relevant for certain legal relationships (such as rules on the law applicable to contracts, torts or divorce). It rather contains a general part consisting of legal principles that effect the determination of the law applicable to various legal relationships (Rühl \& von Hein, 2015, p. 703)

\section{Conclusions}

The interaction between theory and practice in methodology should be the basis of the study. Methodology solves the problems posed by practice and vice versa, the problems of practice lead to the construction of rational legal constructions. Thus, we can easily summarize the article's main arguments by suggesting the new definition of term "methodology" through two key meanings: 1) a system of methods and techniques used in a particular field of activity and 2) the doctrine of such a system as general theory of method, theory in action. Methodology is also based on a system of principles, which are enshrined, including in Article 3 of the Civil Code of Ukraine, and, in connection with the implementation of private international law in national law, become the rules formulated in the Principles, Definitions and Model Rules Private European Law, Principles of European Contract Law (PECL), Principles of European Law (PEL), Principles of European Insurance Law, Principles of Acquis, Principles of UNIDROIT. The results of our empirical analysis provide strong evidence that the interaction between theory and practice in methodology should be the basis of the study, because it is methodology which solves the problems posed by practice and vice versa, the problems of practice lead to the creation of rational legal constructions.

\section{References:}

Bar, C., Clive, E. and Schulte-Nölke, H. (2009) Principles, Definitions and Model Rules of European Private Law. Draft Common Frame of Reference (DCFR). De Gruyter european law publishers. 643 p. https://doi.org/10.1515/9783866537279 (in English).

Barnes, K. (2020) Refraiming Housing: Incorporating Public Law Principles into Private Law. Duke J. Comp. EंIntl L. Pp. 89-103 (in English).

de Bérier, F.L. (2015) Remarks on the methodology of private law studies: The use of Latin maxims as exemplified by nemo plus iuris. Fundamina (Pretoria). vol. $21 \mathrm{n}$. 1. http://dx.doi.org/10.17159/2411-7870/2015/v21n1a4 http://www.scielo.org.za/scielo.php?pid=S 1021-545X2015000100004\&script=sci_arttext\&tlng=es (in English).

Bodnar, T.V. (2007) Dohovirni zoboviazannia v tsyvilnomu pravi : Zah. polozhennia. [Contractual obligations in civil law: General. position] K.: Yustinian. 280 s (in Ukrainian).

Brudner, A. (2011) Understanding Law on its Own Terms: Essays on the occasion of Ernest Weinrib`s Killiam Prize. The University of Toronto Law Journal. Vol. 61, No. 2, (Spring 2011), pp. 279-311 (in English).

Dovgert, A.S. (2012) Vstup do kursu «Mizhnarodne pryvatne pravo» [Introduction to the course "Private International Law"] Law of Ukraine. № 9. S. 238-255 (in Ukrainian).

Gold, A.S., Goldberg, J. C. P., Kelly, D. B., Sherwin, E.L., and Smith, H.E., etc. (2019) Internal and External Perspectives: On Methodology in the New Private Law. The Oxford Handbook of New Private Law (in English).

Krupchan, O.D. (2016) Metodolohichni vymiry suchasnoho vitchyznianoho pryvatnoho prava [Methodological dimensions of modern domestic private law. Methodology of private law (theoretical discourse and practical application): materials intern. scientific-theoretical conf.] (Kyiv, June 10, 2016). K: Research Institute of Private Law and Entrepreneurship named after Academician F. G. Burchak NAPRN of Ukraine. S. 9-18 (in Ukrainian).

Liang, C. (2020) The application of administrative law principles in private law: The case for convergence. Singapore Journal of Legal Studies. Pp. 427-428 (in English).

Maidanyk, R. (2019) Vchennia pro metodolohiiu pryvatnoho (tsyvilnoho) prava Ukrainy. Zahalni polozhennia. [The doctrine of the methodology of private (civil) law of Ukraine. Terms]. Law of Ukraine. №1. P.58-74. DOI 10.33498/louu-2019-01-058 (in Ukrainian).

Principles, Definitions and Model Rules of European Private Law. Full Edition. Prepared by the Study Group on a European Civil Code and the Research Group on EC Private Law (Acquis Group) / Ed. by Christian von Barand, Eric Clive. Vol. I - VI. Munich, 2009. 320 p. (in English).

Rabinovych, P. M. (2001) [Methodology of legal science. Legal encyclopedia: in 6 volumes] edkol. Yu. S. Shemshuchenko (holova redkol.) tain. Kyiv: Ukr. entsykl., T. 3: K - M. S. 618-627 (in English).

Rühl, G., von Hein, J. (2015) Towards a European Code on Private International Law? The Rabel Journal of Comparative and International Private Law. Bd. 79, H. 4 (Oktober 2015), pp. 701-751 (in English). 
Vasyliev, V. V. (2018) Dyspozytyvnist norm tsyvilnoho prava z tochky zoru formalno dohmatychnoho pidkhodu [Dispositiveness of civil law from the point of view of a formally dogmatic approach] Entrepreneurship, economy and law. № 12. S. 10-14 (in Ukrainian).

Verstein, A. (2019) Privatizing Personalized Law. The University of Chicago Law Review. Vol. 86, No. 2, Symposium: Personalized Law (March 2019), pp. 551-580 (in English).

Yuldashev, O.H. (2004) Mizhnarodne pryvatne pravo: Teoretychni ta prykladni aspekty [International private law: Theoretical and applied aspects]. K.: MAUP 576 s (in Ukrainian).

\section{Наталія Процьків,}

кандидат юридичних наук, доцент, доцент кафедри приватного права юридичного факультету, Чернівещький національний університет імені Юрія Федьковича, вул. Університетська, 19, Чернівиі, Україна, індекс 58012, n.protskiv@сhпи.еdu.иа

ORCID: orcid.org/0000-0002-2182-4936

\section{Оксана Кіріяк,}

кандидат юридичних наук, доцент, доцент кафедри приватного права юридичного факультету, Чернівещький національний університет імені Юрія Федьковича, вул. Університетська, 19, Чернівиі, Україна, індекс 58012, о.kiriyak@сhпи.еdu.иа

ORCID: orcid.org/0000-0001-8850-805X

\section{ДО ПИТАННЯ МЕТОДОЛОГІЇ ПРИВАТНОГО ПРАВА}

Анотація. Метою статті є обгрунтування впливу методології приватного права на процеси законотворчості та правозастосування.

Методи дослідження. Роботу виконано на підставі загальнонаукових і спеціальних методів наукового пізнання.

Результати. Проаналізовано взаємозв'язок теорії та практики в методології приватного права. Зокрема, визначено, що поняття «методологія» має два основні значення: по-перше, система способів і прийомів, які застосовуються в певній сфері діяльності, а по-друге, учення про таку систему, загальна теорія методу, теорія в дії. Автори виділяють основні ознаки методу регулювання приватноправових відносин: юридичну рівність учасників, вільне волевиявлення сторін, їх ініціативність, майнову самостійність, використання диспозитивних норм. У зв'язку із цим для приватного права традиційно характерний диспозитивний метод, який дає змогу учасникам відносин вільно діяти в межах урегульованих законом правовідносин. Зазначається, що основою методології є також система принципів, які закріплені, зокрема, у статті 3 Цивільного кодексу України та у зв'язку з імплементацією норм міжнародного приватного права в національне законодавство набувають значення правил. Ці принципи сформульовані у Принципах, дефініціях і модельних правилах європейського приватного права (DCFR), Принципах європейського договірного права (PECL), Принципах європейського права (PEL), Принципах європейського страхового права, Принципах acquis, Принципах УНІДРУА. У правозастосовній практиці спостерігається зростання інтересу до використання цих принципів.

Висновки. Встановлено, що зв'язок теорії та практики в методології має бути основою дослідження. Методологія вирішує проблеми, які поставлені практикою, і навпаки, проблеми практики приводять до побудови раціональних правових конструкцій.

Ключові слова: методологія, практика, принципи, методи, норми, приватне право. 